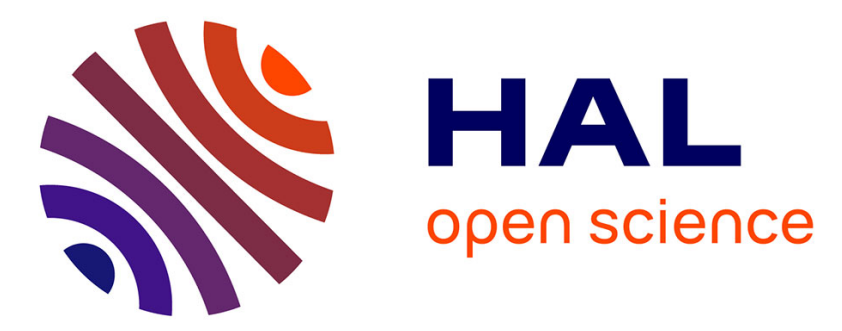

\title{
Signals of tree volume and temperature in a high-resolution record of pollen accumulation rates in northern Finland
}

Florence Mazier, Anne Brigitte Nielsen, Anna Brostrom, S. Sugita, S. Hicks

\section{- To cite this version:}

Florence Mazier, Anne Brigitte Nielsen, Anna Brostrom, S. Sugita, S. Hicks. Signals of tree volume and temperature in a high-resolution record of pollen accumulation rates in northern Finland. Journal of Quaternary Science, 2012, 27 (6), pp.564-574. halshs-00959849

\section{HAL Id: halshs-00959849 \\ https://shs.hal.science/halshs-00959849}

Submitted on 17 Mar 2014

HAL is a multi-disciplinary open access archive for the deposit and dissemination of scientific research documents, whether they are published or not. The documents may come from teaching and research institutions in France or abroad, or from public or private research centers.
L'archive ouverte pluridisciplinaire HAL, est destinée au dépôt et à la diffusion de documents scientifiques de niveau recherche, publiés ou non, émanant des établissements d'enseignement et de recherche français ou étrangers, des laboratoires publics ou privés. 


\title{
Signals of tree volume and temperature in a high-resolution record of pollen accumulation rates in northern Finland
}

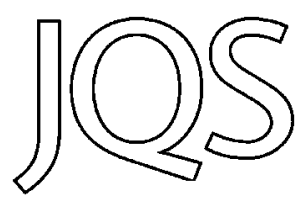

\author{
F. MAZIER, ${ }^{1,2 *}$ A. B. NIELSEN, ${ }^{2,3}$ A. BROSTRÖM, ${ }^{2}$ S. SUGITA ${ }^{4}$ and S. HICKS ${ }^{5}$ \\ ${ }^{1}$ Laboratoire GEODE, UMR 5602, Université de Toulouse-Le Mirail, 5 allées A. Machado, 31058 Toulouse Cedex, France \\ ${ }^{2}$ Department of Geology, Lund University, Sweden \\ ${ }^{3}$ Department of Palynology and Climate Dynamics, Göttingen University, Germany \\ ${ }^{4}$ Institute of Ecology, Tallinn University, Estonia \\ ${ }^{5}$ Institute of Geosciences, Oulu University, Finland
}

Received 23 November 2011; Revised 14 March 2012; Accepted 20 March 2012

\begin{abstract}
Pollen accumulation rates (PARs) provide a potential proxy for quantitative tree volume $\left(\mathrm{m}^{3} \mathrm{ha}^{-1}\right)$ reconstruction with reliable absolute pollen productivity estimates (APPEs). We obtained APPEs for pine, spruce and birch at their range limits in northern Finland under two temperature periods ('warm' and 'cold') based on long-term

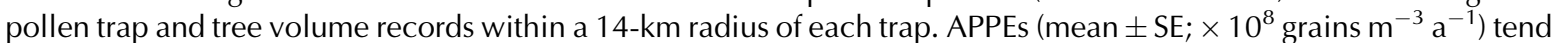
to be higher for the 'warm' periods (pine 123.8 \pm 24.4 , birch 528.0 \pm 398.4 , spruce $434.3 \pm 113.7$ ) compared with the 'cold' periods (pine $95.5 \pm 37.3$, birch $317.3 \pm 282.6$, spruce $119.6 \pm 37.6$ ), although the difference is only significant for spruce. Using an independent temperature record and the APPEs obtained, we reconstruct a low-frequency record of pine volume changes over the last 1000 years at Palomaa mire, where a high-resolution record of Pinus PARs is available. Five phases are distinguished in the reconstruction: moderate pine volume, AD 1080-1170; high volume, AD 1170-1340; low volume, AD 1340-1630; very low volume, AD 1630-1810; and rising pine volume, AD 18101950. These phases do not coincide with periods of high or low June-July-August temperatures, and thus appear to reflect regional variations in tree volume, while high-frequency changes within each time-period block show variations in PARs in response to temperature. Copyright (C) 2012 John Wiley \& Sons, Ltd.
\end{abstract}

KEYWORDS: pollen accumulation rates; absolute pollen productivity; northern boreal forest; Pinus sylvestris; tree volume reconstruction.

\section{Introduction}

Reconstructions of past vegetation from fossil pollen assemblages are increasingly being based on pollen accumulation rates (PARs, grains $\mathrm{cm}^{-2} \mathrm{a}^{-1}$ ) (Seppä and Hicks, 2006; Giesecke and Fontana, 2008; Kuoppamaa et al., 2009a) rather than using the more classical approach based on pollen percentages. Although several technical issues remain, such as inherent difficulties in evaluating accumulation rates of sediments, within- and between-site variations in pollen concentrations and PARs, the use of PARs overcomes some of the problems involved in using pollen percentages in vegetation reconstruction. The changes in PARs of individual taxa through time, in theory, reflect population abundance of each taxon in an absolute unit within the source area of the deposited pollen (Davis and Deevey, 1964; Prentice, 1985; Sugita, 1994). This is particularly helpful in situations where the vegetation is species poor and dominated by one or two tree taxa. Furthermore, extensive dispersal of pollen from forested communities into unforested ones can be problematical for estimating the dynamics of forest limits and landscape openness based on percentage data. PAR-based reconstructions can potentially be more informative for those situations.

There are three main factors that affect the relationships between plant abundance and pollen deposition, and thus PAR-based reconstruction, at a given site: (i) the amount of pollen produced by individual trees, (ii) the density and age of the trees within the pollen source area and (iii) the distance of each tree from the point where the pollen is deposited. The amount of pollen produced by a tree depends on its age and

*Correspondence: F. Mazier, Laboratoire GEODE, as above.

E-mail: florence.mazier@univ-tlse2.fr growth form (e.g. growing as a canopy or an understorey tree). In addition, there is considerable annual variation in response to temperature conditions, particularly at the range limits of trees (Hicks, 2001; Hicks et al., 2001; Huusko and Hicks, 2009). When temperature conditions are favourable an individual tree may produce far more pollen than it will under unfavourable temperature conditions, while with particularly harsh conditions it may not produce any pollen at all. In the short term (1-5 years), forest composition, age and location do not change significantly, with the exception of large-scale felling or destruction by fire, so the greatest influence on pollen deposition would be temperature-induced changes in pollen production. In the long term (50s to 100 s of years), however, it is changes in the density, age and biomass of the trees that will have a greater influence on pollen deposition, even if these are ultimately caused by climate.

The main aim of this study was to evaluate the extent to which the PAR record from a small mire at Palomaa in northern Finland (Fig. 1) can be used to reconstruct past changes in tree volume $\left(\mathrm{m}^{3} \mathrm{ha}^{-1}\right)$. This region is ideal for this project. Based on the extensive pollen-monitoring records using a network of pollen traps over the past 25 years (Hicks, 2001), Sugita et al. (2010) obtained absolute pollen productivity estimates (APPEs) (grains $\mathrm{m}^{-3} \mathrm{a}^{-1}$ ) - an important parameter for the reconstruction of past changes in tree volume in the region - for Pinus, Picea and Betula spp. Huusko and Hicks (2009) show, however, that there is a strong correlation between both Pinus and Picea pollen deposition and July temperature of the year before pollen emission in the same region. For Pinus, in years where July temperature falls below $12^{\circ} \mathrm{C}$, its pollen deposition in the following years falls by more than $50 \%$. For Picea, the comparable threshold is a July temperature of $13{ }^{\circ} \mathrm{C}$. The relationship between PAR and a temperature threshold, 


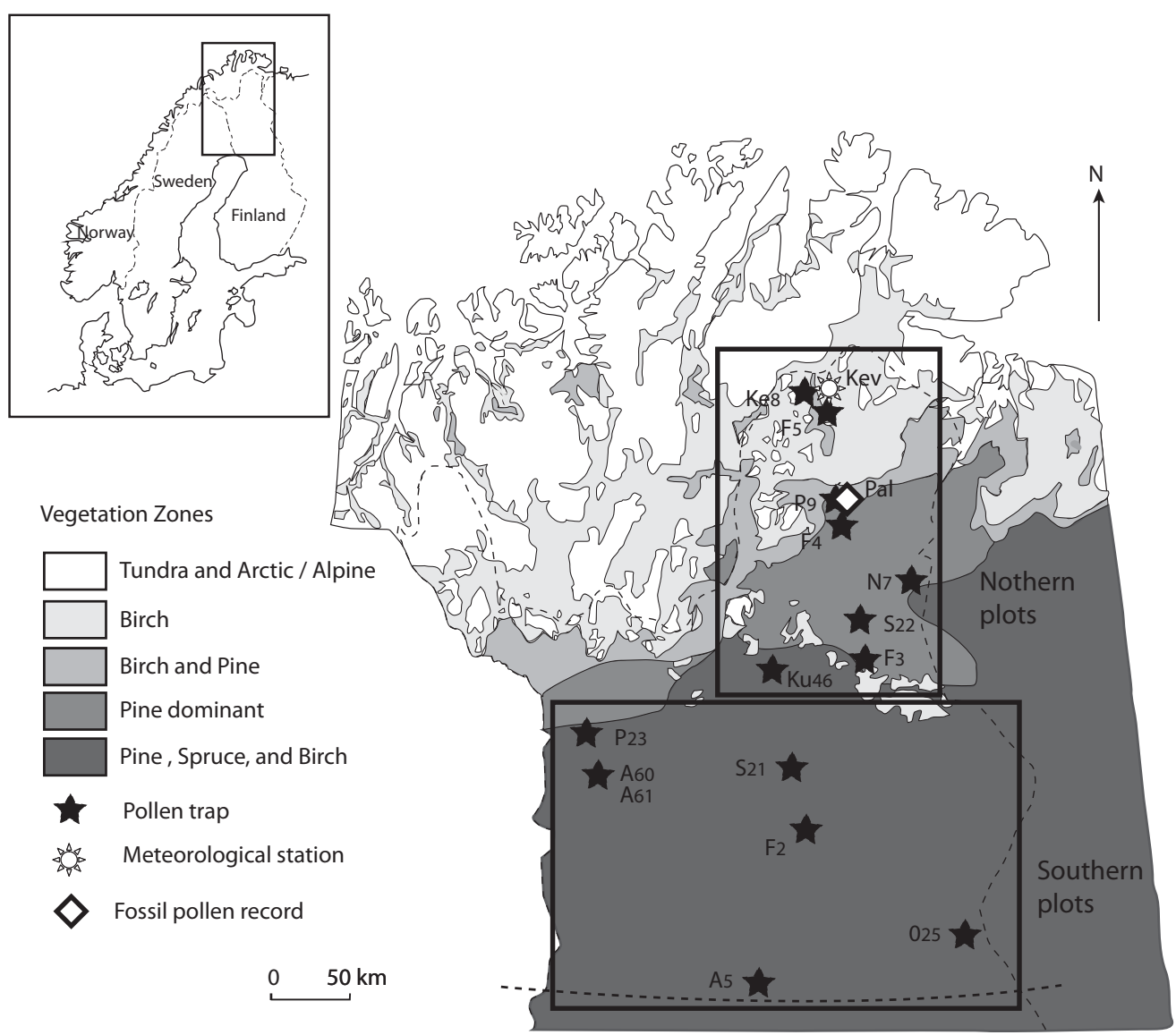

Figure 1. Map of northern Finnish Lapland indicating the regional vegetation belts, the location of the 15 pollen monitoring sites, the Palomaa (Pal) peat profile and the meteorological station of Kevo (Kev). The division between the northern and southern plots is also shown.

although significant over a relatively wide geographical area (northern Finland), is stronger at the forest limit than within the main range of the tree (Huusko and Hicks, 2009).

Based on these results we are able to evaluate the pollen-tree volume relationships in 'warm' and 'cold' periods according to the threshold of the July temperature of the previous year $\left(T_{\text {July-1 }}\right)$ for those taxa in the region. If APPEs differ between the 'warm' and 'cold' periods, those two sets of APPEs would influence tree volume estimates reconstructed from the fossil PAR record. In addition, an independent temperature record over the last 1000 years is available in the region, based on a combined set of nine tree-growth parameters (Young et al., 2012). Thus, it is possible to evaluate objectively the effects of the temperature-dependent differences, if any, in APPEs on the tree volume reconstruction.

This study first evaluates APPEs of Pinus, Picea and Betula spp. during the 'warm' and 'cold' periods in the region over the last 25 years, using the long-term monitoring records of 15 pollen traps (Hicks, 2001; Sugita et al., 2010) and presentday tree volume estimates within a $14-\mathrm{km}$ radius from each trap. Secondly, we use a high-resolution 1000-year record of PARs from a small mire at Palomaa to reconstruct the changes in Pinus volume in the region by taking into account the independent climate record and APPEs obtained in the first step of the study.

Hereafter, we use the term 'pollen loading' to represent the amount of pollen deposited in pollen traps and on the mire surface, assuming that all post-depositional mechanisms and factors that affect the composition and abundance of pollen in peat are negligible (Sugita, 1994; Sugita et al., 2010). It is known that there are differences between the pollen deposited in a trap and pollen incorporated in an adjacent moss (Lisitsyna et al., 2012) or pollen extracted from an adjacent peat profile (Bennett and Hicks, 2005) but this is primarily in the proportion of the dwarf shrubs and is only relevant when the results are expressed as percentages. The PAR of Pinus is not affected. Kuoppamaa et al. (2009b) show that although there is a smoothing of about 5 years for Pinus PARs recorded in a high-resolution peat profile compared with the Pinus PAR record in a pollen trap, the July temperature signal was still retained. The 'smoothing' occurs because a 1-year slice from the peat actually represents somewhat more or sometimes less than a calendar year (flowering season). At Palomaa the 'smoothing' as recorded by the dating in the upper $30 \mathrm{~cm}$ of the profile is \pm 2 years (T. Goslar, Poznan University, Poland, pers. comm., 2011). For reconstruction purposes, we also assume that PARs are equivalent to the pollen loading in the model applied for estimating the changes in tree volume of Pinus at Palomaa.

\section{Methods}

\section{Current dataset}

Pollen traps and pollen loading data

The pollen trap dataset used here comprises records from 15 sites (Fig. 1; Hicks, 2001; Sugita et al., 2010) and covers the period 1982-2007. The network of 15 pollen traps extends from the birch-dominated region in the north, through the pinedominated area to the mixed pine-spruce-birch region in the south, ranging from $\sim 70^{\circ}$ to $\sim 66^{\circ} 30^{\prime} \mathrm{N}$ in latitude and from $\sim 29^{\circ} 20^{\prime}$ to $\sim 24^{\prime} \mathrm{E}$ in longitude (Fig. 1).

Pollen data have been collected annually after the end of the flowering season (September) following a standardized procedure (Hicks et al., 1996, 1999) in accordance with the Pollen Monitoring Programme (http://www.pollentrapping.net). The pollen loading of the traps was calculated using added exotic marker grains (Hicks, 1994). For data analysis, we use the 
original pollen loading data from each year during the entire monitoring period. Three sets of site combinations are considered to evaluate the regional differences in pollen productivity (Sugita et al., 2010): (i) northern plots $(n=8)$ from the pine- and birch-dominated regions, (ii) southern plots $(n=7)$ from the region of mixed pine, spruce and birch, and (ii) all plots $(n=15)$ combining the northern and southern plots.

Moreover, to assess whether the mean July temperature of the previous year $\left(T_{\text {July } 1}\right)$ affects absolute pollen productivity estimates (APPEs), we selected two distinct sampling periods for each species, i.e. 'cold' and 'warm' sampling years, based on the threshold value $12{ }^{\circ} \mathrm{C}$ (for Pinus and Betula) and $13{ }^{\circ} \mathrm{C}$ (for Picea) (Fig. 2), using temperature data from the monitoring site at Kevo (Fig. 1). The number of pollen traps available varies from seven to 15 in any given year and the number of sampling years varies from five to 20 between cold and warm periods.

\section{Meteorological data}

Meteorological data (monthly temperature) from Kevo (northern plot, Fig. 1) are available for the pollen monitoring period. The temperature record is assumed to be relevant for all the sites (northern and southern sites), even though, because of their geographical location, the southern plots have slightly higher temperatures than the northern plots. It is clear that for the whole of the area considered annual temperature variations are synchronized (Huusko and Hicks, 2009). The mean July temperature of the previous year $\left(T_{\text {July }_{1}}\right)$ of pollen emission varies between 10.7 and $17.2^{\circ} \mathrm{C}$ through the pollen monitoring period (Fig. 2).

\section{Vegetation data}

We used tree volume estimates $\left(\mathrm{m}^{3} \mathrm{ha}^{-1}\right)$ for pine (Pinus sylvestris), spruce (Picea abies) and birch (Betula pubescens subsp. pubescens and $B$. pubescens subsp. czerepanovii treated as one taxon) previously published by Sugita et al. (2010). The original vegetation database was compiled in 1992-1994 by the National Land Survey of Finland (2002), which gives the average volume $\left(\mathrm{m}^{3} \mathrm{ha}^{-1}\right)$ of the growing stock based on field plot data, optical area satellite images and digital maps (Katila and Tomppo, 2001). It specifies tree volume classes at every $25-\mathrm{m} \times 25-\mathrm{m}$ grid cell in a $123-\mathrm{km} \times 181-\mathrm{km}$ area for the northern plots and in six ca. $20-\mathrm{km} \times 20-\mathrm{km}$ for the southern plots. The tree volume classes have been reclassified according to Räsänen et al. (2007) to estimate tree volume in each grid cell (Sugita et al., 2010). There have been no dramatic decreases in tree abundance due to fire or felling around the pollen trap sites during the pollen monitoring period, so the plant volume data are assumed to reflect the surrounding vegetation during the whole period (1982-2007).

According to the Prentice model of pollen dispersal and deposition (Prentice, 1985), $>80 \%$ of pine and birch pollen and $>95 \%$ of spruce pollen is considered to come from within a $14-\mathrm{km}$ radius for a sedimentary basin $<1.0$ ha (Sugita, 1993). Thus, mean tree volume $\left(\mathrm{m}^{3} \mathrm{ha}^{-1}\right)$ was calculated at $25-\mathrm{m}$ intervals from each pollen-trap location out to $14 \mathrm{~km}$ using all the available vegetation data (Sugita et al., 2010).

\section{Fossil dataset}

The small mire of Palomaa (3.32 ha; $69^{\circ} 16^{\prime} 39.02^{\prime \prime} \mathrm{N}$, $27^{\circ} 11^{\prime} 39.09^{\prime \prime} \mathrm{E}, 104 \mathrm{~m}$ a.s.l.) is located just north of the current northern limit of continuous pine forest so that the regional vegetation is formed by both pine and the two subspecies of birch (Betula pubescens subsp. pubescens and B. pubescens subsp. czerepanovii). The northern limit of spruce is some $100 \mathrm{~km}$ to the south (Hicks, 2001) (Fig. 1). This location corresponds with the $12{ }^{\circ} \mathrm{C}$ July temperature isotherm (Huusko and Hicks, 2009) and the 600 growing degree-days above $5{ }^{\circ} \mathrm{C}$ isoline. The mire is a string mire where the wet flarks are dominated by Eriophorum vaginatum, Trichophorum caespitosum and Carex spp., while the strings, which are mostly composed of Sphagnum fuscum, support Betula nana, Empetrum nigrum, Vaccinium uliginosum, Vaccinium oxycoccus, Ledum palustre, Andromeda polifolia and Rubus chamaemorus.

The area is remote from habitation and the only disturbance to the natural vegetation is a road which runs past the mire at a distance of $150 \mathrm{~m}$. This road, originally of gravel, was built in AD 1959, surfaced some 20 years later and rebuilt and realigned in 1989-1991. Ditching along the roadside in connection with the road building and the construction of a culvert to take water under the road may have influenced the hydrology of the mire over the last 50 years (W. Finsinger, Montpellier University, France, pers. comm., 2011).
Figure 2. Division of the period AD 1982-2007 into 'cold' and 'warm' years on the basis of mean July temperature of the year before pollen emission $\left(T_{\text {july-1 }}\right)$, which is known to affect pollen production and deposition (Huusko and Hicks, 2009).

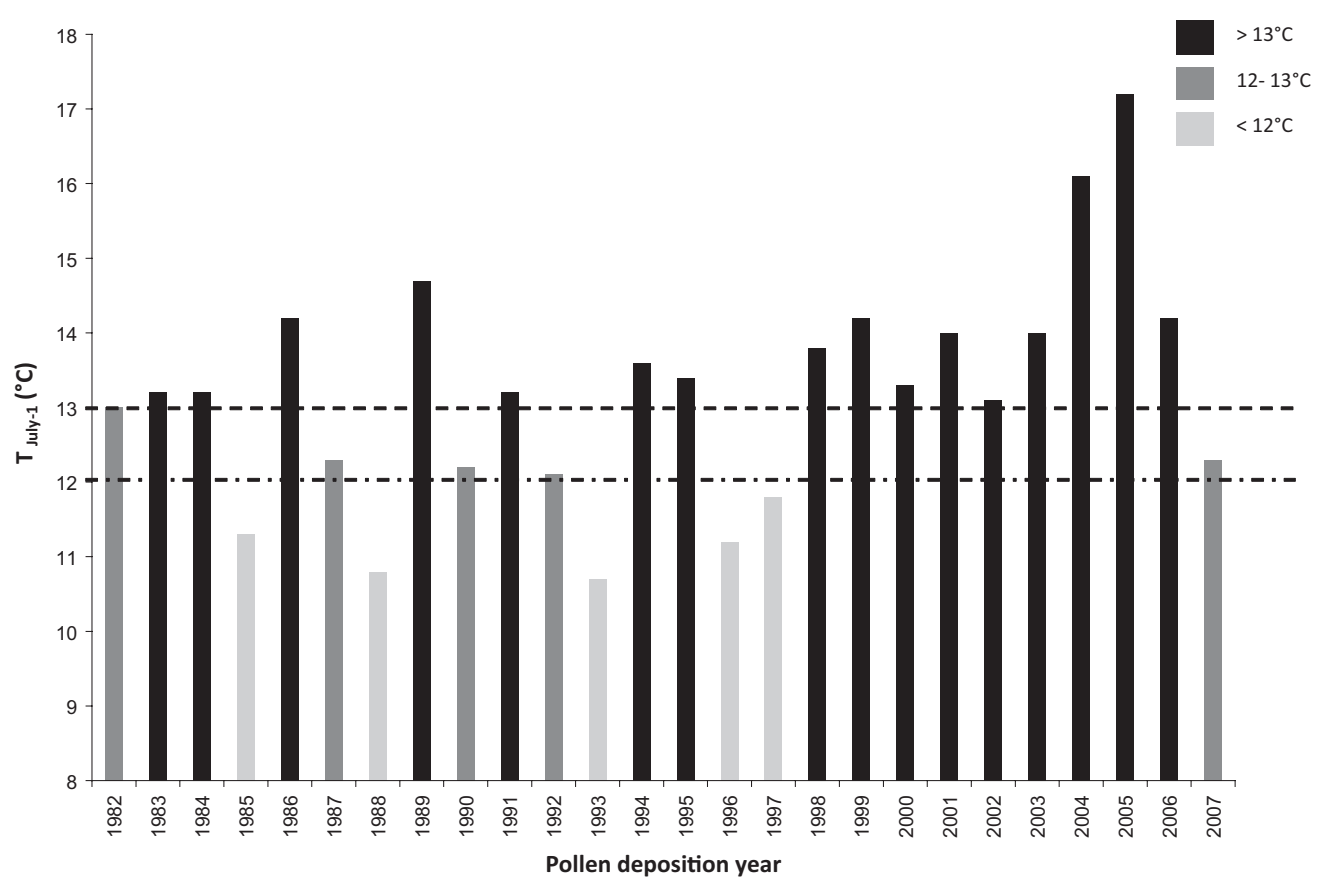




\section{Fossil pollen accumulation rates}

A peat monolith for high-temporal-resolution pollen analysis was dug with a spade in 2005 from a Sphagnum fuscum string hummock. The depth of peat obtained was $52 \mathrm{~cm}$, of which $45 \mathrm{~cm}$ proved to cover just over the last 200 years (W. Finsinger, pers. comm., 2011). To extend the record further back in time a second peat monolith was taken adjacent to the first in 2007 by means of a Clymo corer (Clymo, 1998). This extended the peat profile down to a depth of $64 \mathrm{~cm}$. Of this second peat core, $14 \mathrm{~cm}$ was analysed, covering 800 years, so that the combined record used here covers the last 1000 years. Both profiles were dated with radiocarbon analyses (30 samples of Sphagnum, both stems and branches but with other plant material and humus removed) which showed that the AD 1963 bomb peak of atmospheric ${ }^{14} \mathrm{C}$ concentration occurs at a depth of $26 \mathrm{~cm}$ in both so that the depths between them match (T. Goslar, pers. comm., 2011). A robust age-depth model was established using the program developed by Goslar et al. (2005, 2009). From frozen peat blocks $3 \times 5 \mathrm{~cm}$ in surface area, 249 samples were cut as a continuous series, 135 from the first monolith and 114 from the Clymo core with the two peat sections overlapping by seven samples (1.4 cm and 41 years). Sample thickness in the monolith was either $0.4,0.3$ or $0.2 \mathrm{~cm}$ and in the Clymo section was consistently $0.2 \mathrm{~cm}$. This means that for the past 50 years each sample represents close to 1 year of sediment accumulation based upon the age-depth model, and for the 50-year period before that around 2 years. The temporal resolution then decreases so that for the period $100-500$ years ago each sample represents from 4 to 7 years and for the period 500-1000 years ago 10-15 years (T. Goslar, pers. comm., 2011). Using fastgrowing peat and sampling in very thin consecutive slices, it is possible to produce near-annual PAR series for the last 50 years, but even these 'annual' series do not correspond to annual flowering periods.

To calculate the pollen concentration in the individual peat samples, marker grains (Lycopodium tablets, Stockmarr, 1971) were added at the beginning of the chemical preparation. The concentration value for each sample was converted to PARs by dividing by the number of years that each sample represents. The standard error (SE) on this PAR estimate is a combination of a set of factors: the SE on the number of added Lycopodium spores per tablet, the error due to the ratio calculation between the marker grains added and the marker grains counted (Mosimann, 1965; Maher, 1981), the calibration error on the radiocarbon measurement, and the range of error on the age-depth chronology (T. Goslar, pers. comm., 2011). The following equation is used to estimate the SE of PAR according to the delta method (Stuart and Ord, 1994):

$$
S E(P A R) \cong \sqrt{(C \cdot S E(r))^{2}+(r \cdot S E(C))^{2}+2 \cdot C \cdot r \cdot \operatorname{cov}(C, r)}
$$

where PAR represents the pollen accumulation rates [grains $\mathrm{cm}^{-2} \mathrm{a}^{-1}$ ], $C$ the pollen concentration [grains $\mathrm{cm}^{-3}$ ], $r$ the sediment accumulation rates $\left[\mathrm{cm} \mathrm{a}^{-1}\right], S E(P A R)$ the standard error of the pollen accumulation rates [grains $\mathrm{cm}^{-2} \mathrm{a}^{-1}$ ], $\mathrm{SE}(C)$ the standard error of the pollen concentrations [grains $\mathrm{cm}^{-3}$ ], $\mathrm{SE}(r)$ the standard error of the sediment accumulation rates $\left[\mathrm{cm} \mathrm{a}{ }^{-1}\right]$ and $\operatorname{cov}(C, r)$ the covariance of $C$ and $r$. We assume that the pollen concentration $C$ and sediment accumulation rates $r$ are independent variables for this model to approximate SE of PARs. In reality $C$ and $r$ may not be completely independent; however, we treat these two variables as independent for the sake of simplicity. Accordingly, it is reasonable to assume that the covariance term in Eq. (1) is negligible. Equation (1) then becomes:

$$
S E(P A R) \cong \sqrt{(C \cdot S E(r))^{2}+(r \cdot S E(C))^{2}}
$$

SE(C) was estimated according to Maher's model (1981), with the assumption that there is no error in volume estimate of sediment, as it was not possible to calculate the error on the sample volume. $\mathrm{SE}(r)$ was calculated on the basis of the agedepth model (T. Goslar, pers. comm., 2011). For data analysis this study did not use the section of the profile after AD 1959. For the last 50 years the peat accumulation has been so fast that for some sections of the peat each sample represents slightly less than 1 year and the pollen content is very low. In the post AD 1959 section it was often impossible to achieve a statistically acceptable terrestrial pollen sum, and in many samples the number of marker grains encountered was unacceptably low.

The complete 1000-year pollen record indicates that pine and birch were the only trees present in the region and that pine has always been overwhelmingly dominant (W. Finsinger, pers. comm., 2011). Picea pollen is recorded in small amounts but the tree itself cannot have been present nearby, as the pollen quantities during this period are of the same order as at the present day. Moreover, the bedrock of this region produces soil and edaphic conditions which are unsuitable for spruce (Sutinen et al., 2005). Therefore, spruce was omitted from the tree volume reconstruction. The negligible charcoal record indicates that there have been no major fires. The vast majority of the charcoal particles recorded were smaller than $40 \mu \mathrm{m}$ in size and the quantity of these was generally $<20$ particles $\mathrm{cm}^{-2} \mathrm{a}^{-1}$.

\section{Palaeoclimate data}

The most robust independent palaeoclimate data available are a reconstruction of mean June, July and August (JJA) temperature based on a combination of tree growth parameters, i.e. ring width, maximum late wood density and annual height increments (nine proxy series in all), from four sites along a transect from the west coast of Norway to the Kola peninsula at around $69^{\circ} \mathrm{N}$ (Young et al., 2012). As Palomaa is located at $69^{\circ} \mathrm{N}$ this temperature record based on tree-growth patterns in the period AD 800-2004 is highly appropriate for comparison. Analysis of the instrumental temperature records at Kevo in northern Finland (Fig. 1) during the period 1962-2008 shows that the correlation between average JJA temperature and July temperature is high and that whenever July temperature is $12^{\circ} \mathrm{C}$, mean JJA is $11^{\circ} \mathrm{C}$.

\section{Data analysis}

\section{Absolute pollen productivity}

Absolute pollen productivity was estimated for pine (Pinus sylvestris), spruce (Picea abies) and birch (Betula pubescens, without separating the subspecies of pubescens and czerepanovii) for each of two distinct temperature periods ('cold' and 'warm', based on $\left.T_{\text {July-1 }}\right)$. The cutoff between 'warm' and 'cold' was set at $12^{\circ} \mathrm{C}$ for Betula and Pinus, and $13{ }^{\circ} \mathrm{C}$ for Picea, as discussed above. Absolute pollen productivities (grains $\mathrm{m}^{-3} \mathrm{a}^{-1}$ ) are estimated based on the pollen loading data from the traps and the distance-weighted plant abundance $\left(\mathrm{m}^{3} \mathrm{ha}^{-1}\right)$ of individual taxa in a $14-\mathrm{km}$ radius around all trap sites, using Prentice's model of pollen dispersal and deposition (Prentice, 1985). For distance weighting, the radius of the sedimentary basin of all traps was set to $0.1 \mathrm{~m}$, a size comparable with the cover of the traps used for monitoring. As in Sugita et al. (2010), we assumed a wind speed of $3.0 \mathrm{~m} \mathrm{~s}^{-1}$ based on meteorological data from Kevo, neutral atmospheric conditions and fall speed of pollen $\left(\mathrm{m} \mathrm{s}^{-1}\right)$ of 0.056 for Picea, 0.031 for Pinus, and 0.024 for Betula. 
A linear regression method specifically designed to use more than one value of $y$ for each value of $x$ (Sokal and Rohlf, 1981) was applied to test the relationship between distanceweighted plant abundance in volume around each site $(x)$, and the pollen loading values from individual years $(y)$. Slope (absolute pollen productivity), intercept (background pollen loading), and their standard errors (SE) and 95\% confidence intervals $(\mathrm{Cl})$ are calculated using the method described in Sokal and Rohlf (1981). One-way ANOVA is used to evaluate the differences in pollen loading (original and square-roottransformed values) between sites for each temperature and set of samples. It has been shown that the differences in the results using the two datasets of pollen loading values are small (Sugita et al., 2010), and therefore we present the regression results using original pollen loading data.

\section{Reconstruction of tree volume}

When the vegetation is assumed to be homogeneous, mean plant abundance (tree volume) and its SE within a given area can be calculated based on pollen loading at the given site, pollen productivity in absolute units and using a model for pollen dispersal and deposition (Sugita, 1994).

Pollen loading of species $i$ at site $k, y_{i, k}$ [grains $\mathrm{cm}^{-2} \mathrm{a}^{-1}$ ], coming from between distance $R$ (i.e. site radius) and $Z_{\max }$ (i.e. the maximum spatial extent of the source plant within which most of the pollen originates, and assuming that pollen coming from beyond this distance is negligible), is expressed as:

$$
y_{i, k}=P_{i} \cdot \int_{R}^{z_{\max }} x_{i, k}(z) \cdot g_{i}(z) \cdot d z .
$$

Here, $P_{i}$ represents pollen productivity in absolute unit [grains $\mathrm{m}^{-3} \mathrm{a}^{-1}$ ],$x_{i, k}(z)$ the mean plant abundance of species $i$ at distance $z$ for site $k$ in absolute units $\left[\mathrm{m}^{3} \mathrm{ha}^{-1}\right], z[\mathrm{~m}]$ the distance from a point at the centre of the Palomaa mire, and $g_{i}(z)$ a pollen dispersal-deposition function.

When the surrounding vegetation is assumed to be homogeneous between $R$ and $Z_{\max }$, Eq. (3) can be rewritten as

$$
y_{i, k}=P_{i} \cdot \bar{x}_{i} \cdot \int_{R}^{Z_{\max }} g_{i}(z) \cdot d z
$$

where $\bar{x}_{i}$ is the mean plant abundance of species $i$, which is not a function of distance. When Prentice's model (Prentice, 1985) appropriate for describing pollen loading on mires is used, Eq. (4) becomes

$$
y_{i, k}=P_{i} \cdot \bar{x}_{i} \cdot\left[e^{-b_{i} \cdot R^{\gamma}}-e^{-b_{i} \cdot Z_{\max }^{\gamma}}\right] .
$$

Mean plant abundance (tree volume) of species $i$ is then expressed as

$$
\bar{x}_{i}=\frac{y_{i, k}}{P_{i} \cdot\left[e^{-b_{i} \cdot R^{y}}-e^{-b_{i} \cdot Z_{\max }^{y}}\right]} .
$$

When $\bar{x}_{i}$ is estimated using Eq. (6), its SE can be approximated using the delta method (Stuart and Ord, 1994) as:

$$
\begin{aligned}
S E\left(\bar{x}_{i}\right) \cong & \frac{y_{i, k}}{P_{i} \cdot\left[e^{-b_{i} \cdot R^{y}}-e^{\left.-b_{i} \cdot Z_{\max }^{y}\right]}\right.} \\
& \cdot \sqrt{\left(\frac{S E\left(y_{i, k}\right)}{Y_{i, k}}\right)^{2}+\left(\frac{S E\left(P_{i}\right)}{P_{i}}\right)^{2}} .
\end{aligned}
$$

Because pollen loading $y_{i, k}$ and pollen productivity $P_{i}$ are independently measured and estimated in this study, we assume that those two variables are independent and that the covariance, $\operatorname{cov}\left(y_{i, k}, p_{i}\right)$, is zero in this model. $y_{i, k}$, can represent PARs in this reconstruction formula, assuming that the post-depositional effects on pollen loading of species $i$ at site $k$ are negligible. Note that Eqs (4)-(7) only apply when the vegetation is assumed to be homogeneous, i.e. the abundance of species $i, \bar{x}_{i}$, is the same at all distances from the site out to $Z_{\max }$. This does not apply in heterogeneous vegetation.

All the necessary parameter values for the calculation are the same as those used for calculation of pollen productivity: wind speed of $3.0 \mathrm{~m} \mathrm{~s}^{-1}$, neutral atmospheric conditions and fall speed of pollen of $0.031 \mathrm{~m} \mathrm{~s}^{-1}$ for Pinus. $Z_{\max }$ is set to $14 \mathrm{~km}$.

\section{Results}

\section{Absolute pollen productivity}

The absolute pollen productivity (regression coefficient) estimated for the 'cold' and 'warm' periods is shown in Fig. 3 and Table 1 for all three taxa and all three sets of samples (northern plots, southern plots and both plots combined). When the cold and warm periods are considered separately, the
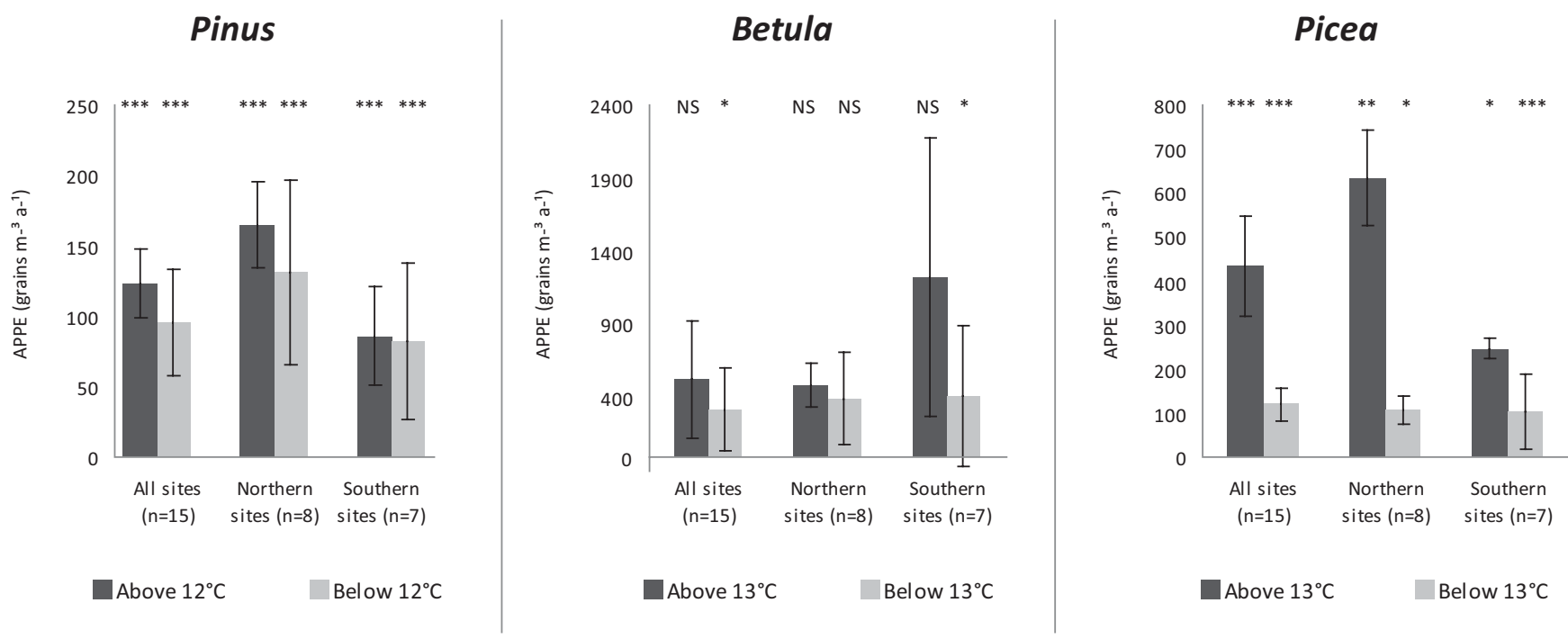

Figure 3. Absolute pollen productivity estimates (APPE, grains $\mathrm{m}^{-3} \mathrm{a}^{-1}$ ) for Pinus, Betula and Picea at each temperature range and set of samples. Error bars indicate the standard error on the pollen productivity estimates. Asterisks above the columns indicate the $P$-values from the associated ANOVA (NS, $P<0.050 ;{ }^{*} 0.010 \leq P<0.05$; $^{* *} 0.001 \leq P<0.01{ }^{* * *} P<0.001$ ). 
Table 1. Regression results and pollen productivity estimates using regression analysis with pollen loading data and distance-weighted plant abundance data.

\begin{tabular}{|c|c|c|c|c|}
\hline $\begin{array}{l}\text { Taxon, and } \\
\text { Pollen trap data }\end{array}$ & $\begin{array}{c}F \text {-value ( } P \text {-value) } \\
\text { among samples }\end{array}$ & $\begin{array}{c}r^{2} \text { for linear } \\
\text { regression }(P \text {-value })\end{array}$ & $\begin{array}{c}\text { Regression } \\
\text { coefficient }(95 \% \mathrm{Cl})\end{array}$ & $\begin{array}{l}\text { Intercept } \\
(95 \% \mathrm{CI})\end{array}$ \\
\hline \multicolumn{5}{|l|}{ Pinus } \\
\hline \multicolumn{5}{|c|}{ Temperature threshold above $12^{\circ} \mathrm{C}$} \\
\hline All plots (15 sites) & $4.99\left(5.79 \times 10^{-8}\right)^{* * *}$ & $0.66\left(2.12 \times 10^{-4}\right)^{* * *}$ & $\begin{array}{c}123.8 \pm 24.4 \\
\text { (71.1 to } 176.5)\end{array}$ & $\begin{array}{c}1690.6 \pm 1136.8 \\
(-550.9 \text { to } 3932.1)\end{array}$ \\
\hline Northern plots (8 sites) & $5.78\left(8.74 \times 10^{-6}\right)^{* * *}$ & $0.83\left(1.71 \times 10^{-3}\right)^{* *}$ & $\begin{array}{c}164.6 \pm 30.6 \\
(89.6 \text { to } 239.6)\end{array}$ & $\begin{array}{c}1442.3 \pm 900.3 \\
(-340.2 \text { to } 3224.8)\end{array}$ \\
\hline Southern plots ( 7 sites) & $4.94\left(2.24 \times 10^{-4}\right)^{* * *}$ & $0.54\left(5.89 \times 10^{-2}\right)^{\mathrm{NS}}$ & $\begin{array}{c}86.0 \pm 35.3 \\
(-4.7 \text { to } 176.1)\end{array}$ & $\begin{array}{c}1623.3 \pm 1116.4 \\
(-296.7 \text { to } 4143.3)\end{array}$ \\
\hline \multicolumn{5}{|c|}{ Temperature threshold below $12{ }^{\circ} \mathrm{C}$} \\
\hline All plots (15 sites) & $23.03\left(4.67 \times 10^{-13}\right)^{* * *}$ & $0.34\left(2.36 \times 10^{-2}\right)^{*}$ & $\begin{array}{c}95.5 \pm 37.3 \\
(15.0 \text { to } 176.0)\end{array}$ & $\begin{array}{c}559.9 \pm 1656.6 \\
(-2810.4 \text { to } 3930.3)\end{array}$ \\
\hline Northern plots (8 sites) & $24.50\left(2.05 \times 10^{-7}\right)^{* * *}$ & $0.40\left(9.23 \times 10^{-2}\right)^{\mathrm{NS}}$ & $\begin{array}{c}131.1 \pm 65.5 \\
(-29.2 \text { to } 291.4)\end{array}$ & $\begin{array}{c}336.6 \pm 1531.9 \\
(-2910.8 \text { to } 3584.0)\end{array}$ \\
\hline Southern plots (7 sites) & $25.53\left(1.30 \times 10^{-7}\right)^{* * *}$ & $0.31\left(1.97 \times 10^{-1}\right)^{\mathrm{NS}}$ & $\begin{array}{c}82.7 \pm 55.65 \\
(-60.3 \text { to } 225.7)\end{array}$ & $\begin{array}{c}662.5 \pm 1816.1 \\
(-3169.3 \text { to } 4494.2)\end{array}$ \\
\hline \multicolumn{5}{|l|}{ Betula } \\
\hline \multicolumn{5}{|c|}{ Temperature threshold above $12{ }^{\circ} \mathrm{C}$} \\
\hline All plots (15 sites) & $1.53\left(0.10 \times 10^{-1}\right)^{\mathrm{NS}}$ & $0.12\left(2.08 \times 10^{-1}\right)^{\mathrm{NS}}$ & $\begin{array}{c}528.0 \pm 398.4 \\
(-332.8 \text { to } 1388.7)\end{array}$ & $\begin{array}{c}1075.3 \pm 1154.1 \\
(-1201.7 \text { to } 3352.2)\end{array}$ \\
\hline Northern plots (8 sites) & $1.49\left(1.78 \times 10^{-1}\right)^{\mathrm{NS}}$ & $0.64\left(1.65 \times 10^{-2}\right)^{*}$ & $\begin{array}{c}485.9 \pm 147.5 \\
(125.0 \text { to } 846.8)\end{array}$ & $\begin{array}{c}861.9 \pm 315.4 \\
(236.7 \text { to } 1487.1)\end{array}$ \\
\hline Southern plots ( 7 sites) & $1.42\left(2.18 \times 10^{-1}\right)^{\mathrm{NS}}$ & $0.25\left(2.56 \times 10^{-1}\right)^{\mathrm{NS}}$ & $\begin{array}{c}1220.8 \pm 951.9 \\
(-1226.1 \text { to } 3667.6)\end{array}$ & $\begin{array}{c}1001.6 \pm 1469.4 \\
(-1926.3 \text { to } 3929.5)\end{array}$ \\
\hline \multicolumn{5}{|c|}{ Temperature threshold below $12^{\circ} \mathrm{C}$} \\
\hline All plots (15 sites) & $1.42\left(1.10 \times 10^{-2}\right)^{*}$ & $0.09\left(2.82 \times 10^{-1}\right)^{\mathrm{NS}}$ & $\begin{array}{c}317.3 \pm 282.6 \\
(-293.3 \text { to } 927.8)\end{array}$ & $\begin{array}{c}843.7 \pm 845.1 \\
(-873.7 \text { to } 2561.1)\end{array}$ \\
\hline Northern plots (8 sites) & $1.85\left(1.42 \times 10^{-1}\right)^{\mathrm{NS}}$ & $0.21\left(2.53 \times 10^{-1}\right)^{\mathrm{NS}}$ & $\begin{array}{c}394.8 \pm 312.4 \\
(-369.6 \text { to } 1159.3)\end{array}$ & $\begin{array}{c}594.8 \pm 688.0 \\
(-856.8 \text { to } 2046.3)\end{array}$ \\
\hline Southern plots ( 7 sites) & $3.96\left(1.16 \times 10^{-2}\right)^{*}$ & $0.13\left(4.32 \times 10^{-1}\right)^{\mathrm{NS}}$ & $\begin{array}{c}409.8 \pm 480.3 \\
(-824.7 \text { to } 1644.4)\end{array}$ & $\begin{array}{c}975.4 \pm 805.4 \\
(-723.9 \text { to } 2674.7)\end{array}$ \\
\hline \multicolumn{5}{|l|}{ Picea } \\
\hline \multicolumn{5}{|c|}{ Temperature threshold above $13^{\circ} \mathrm{C}$} \\
\hline All plots (15 sites) & $5.08\left(8.31 \times 10^{-8}\right)^{* * *}$ & $0.53\left(2.12 \times 10^{-3}\right)^{* *}$ & $\begin{array}{c}434.3 \pm 113.7 \\
(188.7 \text { to } 679.9)\end{array}$ & $\begin{array}{c}67.3 \pm 159.1 \\
(-247.0 \text { to } 381.7)\end{array}$ \\
\hline Northern plots (8 sites) & $3.83\left(1.06 \times 10^{-3}\right)^{* *}$ & $0.85\left(1.12 \times 10^{-3}\right)^{* *}$ & $\begin{array}{c}634.6 \pm 108.9 \\
(368.2 \text { to } 900.9)\end{array}$ & $\begin{array}{c}26.9 \pm 15.8 \\
(-4.4 \text { to } 58.2)\end{array}$ \\
\hline Southern plots ( 7 sites) & $2.28\left(4.71 \times 10^{-2}\right)^{*}$ & $0.19\left(3.32 \times 10^{-1}\right)^{\mathrm{NS}}$ & $\begin{array}{c}246.9 \pm 230.1 \\
(-344.5 \text { to } 838.4)\end{array}$ & $\begin{array}{c}208.0 \pm 308.8 \\
(-408.9 \text { to } 824.8)\end{array}$ \\
\hline \multicolumn{5}{|c|}{ Temperature threshold below $13^{\circ} \mathrm{C}$} \\
\hline All plots (15) & $7.47\left(3.73 \times 10^{-9}\right)^{* * *}$ & $0.44\left(7.23 \times 10^{-3}\right)^{* *}$ & $\begin{array}{c}119.6 \pm 37.6 \\
\text { (38.4 to } 200.8)\end{array}$ & $\begin{array}{c}9.2 \pm 54.0 \\
(-98.5 \text { to } 116.9)\end{array}$ \\
\hline Northern plots (8) & $2.88\left(1.66 \times 10^{-2}\right)^{*}$ & $0.66\left(1.47 \times 10^{-2}\right)^{*}$ & $\begin{array}{c}106.4 \pm 31.4 \\
(29.6 \text { to } 183.3)\end{array}$ & $\begin{array}{c}5.9 \pm 4.2 \\
(-2.5 \text { to } 14.3)\end{array}$ \\
\hline Southern plots (7) & $5.82\left(3.75 \times 10^{-4}\right)^{* * *}$ & $0.23\left(2.73 \times 10^{-1}\right)^{\mathrm{NS}}$ & $\begin{array}{c}103.6 \pm 84.1 \\
(-112.6 \text { to } 319.9)\end{array}$ & $\begin{array}{c}21.1 \pm 110.1 \\
(-203.6 \text { to } 245.7)\end{array}$ \\
\hline
\end{tabular}

Dimension of absolute pollen productivity (i.e. regression coefficient) and background pollen loading coming from beyond $14 \mathrm{~km}$ radius (i.e. intercept) is $\left[\times 10^{8}\right.$ grains $\left.\mathrm{m}^{-3} \mathrm{a}^{-1}\right]$ and [grains $\left.\mathrm{cm}^{-2} \mathrm{a}^{-1}\right]$, respectively. Pollen loading from pollen traps from different geographical areas (northern plots, southern plots and both combined) and from different temperature intervals is tested for differences (NS, $P<0.050 ;{ }^{*} 0.010 \leq P<0.05$; $\left.{ }^{* *} 0.001 \leq P<0.01 ;{ }^{* * *} P<0.001\right)$.

relationships between pollen loading and distance-weighted plant abundance for all three taxa do not differ significantly between the three set of samples considering the 95\% Cls (Table 1).

Table 1 shows that pine and spruce have statistically significant relationships $\left(r^{2}, P<0.05\right)$ between pollen loading and distance-weighted plant abundance when all plots are used, whereas the relationship for birch is only significant when using data from the warm years $\left(T_{\text {July-1 }}\right.$ above $12{ }^{\circ} \mathrm{C}$ ) and from the northern plots. For birch the lower bounds of the $95 \% \mathrm{Cl}$ of the regression coefficients using data from the two temperature periods are below zero (except when using the northern plots and warm years), and thus the APPEs are not significantly different from zero. Therefore, the APPEs of birch are considered to be unreliable and cannot be used for tree volume reconstruction at Palomaa site.

For years with a $T_{\text {July- } 1}$ of above $12^{\circ} \mathrm{C}$, the APPEs (mean \pm $\mathrm{SE} ; \times 10^{8}$ grains $\mathrm{m}^{-3} \mathrm{a}^{-1}$ ) of pine and spruce are highest using the northern plots (pine $=164.6 \pm 30.6$, spruce $=634.6 \pm$ 108.9), lowest using the southern plots (pine $=86.0 \pm 35$, spruce $=246.9 \pm 230.1)$ and intermediate using both plots (pine $=123.8 \pm 24.4$, spruce $=434.3 \pm 113.7$ ). For years with a $T_{\text {July-1 }}$ below $12^{\circ} \mathrm{C}$, the same pattern emerges except for the APPE of spruce, which is highest when using data for all plots, lowest using the southern plots and intermediate using the northern plots. For the two taxa, the lower bounds of the $95 \% \mathrm{Cl}$ of the regression coefficients using the southern plots are below zero independent of the temperature interval used. For pine, the 
lower bound using the northern plots for cold years is also below zero. For those cases, the APPEs are not significantly different from zero; however, the other estimates, especially when using all plots, are considered as robust.

Based on the estimates using both plots, spruce produces more pollen during the 'warm' years than in the 'cold' years. For pine, the APPEs for those two periods are not significantly different considering the $95 \% \mathrm{Cl}$ (Table 1), although there is a tendency for slightly higher values for the 'warm' years (Fig. 3). The SE on the 'cold' year estimates are larger than on the 'warm' year estimates, probably due to the lower number of sampling years included in the analysis, as there were 20 'warm' and only five 'cold' years for Pinus (see Fig. 2).

\section{Reconstruction of tree volume}

In Fig. 4 the reconstructed tree volume of pine using 'warm' and 'cold' APPEs (based on all traps, Fig. 4c) is compared with the reconstructed regional mean JJA temperature, which is smoothed with a 15-year Gaussian filter (Young et al., 2012), hereafter referred to as dendro JJA (Fig. 4a). The $11^{\circ} \mathrm{C}$ cut-off line identifies those points in time when July temperature was probably around $12{ }^{\circ} \mathrm{C}$ (see above). Figure $4(\mathrm{~b})$ shows the changes in PARs. Between AD 1070 and 1950 the reconstructed tree volume of Pinus within a $14-\mathrm{km}$ radius around the Palomaa site varied between $51.2( \pm 22.1)$ and $2.41( \pm 0.7) \mathrm{m}^{3} \mathrm{ha}^{-1}$ (Fig. 4c). There is a tendency for differences in tree volume reconstructions using the APPEs based on warm and cold years for the early part of the record until AD 1650; however, the curves are not significantly different considering the SE estimates. The SEs on the reconstructed tree volume are larger when the APPE for cold years is used and largest for the periods AD 1070-1300 and AD 1920-1950 (Fig. 4c).

Figure 5(a) shows a composite curve produced by taking the reconstruction based on APPEs for the 'warm' years for those periods where the dendro JJA curve exceeds the $11^{\circ} \mathrm{C}$ threshold and the APPEs for the 'cold' years for those periods where JJA temperature falls below $11^{\circ} \mathrm{C}$. This composite curve is plotted overlaying the dendro JJA curve. The curve shows distinct periods of similar tree volume with abrupt changes between them (blocks A-E, Fig. 5b). These are AD 1080-1170 (reconstructed tree volume $22.9 \pm 10.1-38.5 \pm 17 \mathrm{~m}^{3} \mathrm{ha}^{-1}$ ), AD 1170-1340 (28 $\left.\pm 6.9-51.2 \pm 22.1 \mathrm{~m}^{3} \mathrm{ha}^{-1}\right)$, AD 1340 $1630\left(8.1 \pm 3.6-28.3 \pm 12.4 \mathrm{~m}^{3} \mathrm{ha}^{-1}\right)$, AD $1630-1810(<$ $11.6 \pm 4.9 \mathrm{~m}^{3} \mathrm{ha}^{-1}$ ) and from AD 1810 to 1950 increasing values up to $25.9 \pm 12.1 \mathrm{~m}^{3} \mathrm{ha}^{-1}$. These blocks are not distinct in the dendro JJA curve but within each block there are clear relatively short-term peaks and lows that do correspond between the temperature and reconstructed tree volume curves (Fig. 5a), for example high peaks at AD 1270, 1570, 1630, 1760, 1830 and 1940, and distinct lows at AD 1150, 1250, $1350,1460,1560,1610,1720,1770$ and 1840.

\section{Discussion}

\section{Impact of temperature on absolute pollen productivity}

It is known from pollen trap studies not only from this region (Autio and Hicks, 2004; Barnekow et al., 2007; Huusko and Hicks, 2009) but also from other parts of Europe (Andersen, 1980; Nielsen et al., 2010; van der Knaap et al., 2010) that interannual variations in climate conditions affect the pollen loading of different tree species to the pollen traps. The effects vary between regions and species, and can depend both on temperature and precipitation, and on conditions within the flowering season and during the year before, when pollen is formed. For northern Fennoscandia, the most widely reported and strongest relationships are found with summer (July) temperature of the previous year (Autio and Hicks, 2004; Barnekow et al., 2007; Huusko and Hicks, 2009).

It thus seems clear that temperature does affect the production and release of pollen for certain tree species, particularly at the northern range limit, as seen for Picea (Fig. 3). In the present study, we analysed whether this had a significant impact on the quantitative relationship between pollen loading and tree volume. This was the case for Picea, where the slope of the relationship between tree volume and pollen loading (i.e. the APPE) was higher for years where $T_{\text {July-1 }}$ was above $13{ }^{\circ} \mathrm{C}$ than for years below this threshold.

For Pinus and Betula there was a tendency for APPEs to be higher for years above the $T_{\text {July- } 1}=12{ }^{\circ} \mathrm{C}$ threshold than below, but the differences were not statistically significant. Other temperature cut-off values were tried during exploratory data analysis but they did not show clear trends. For Pinus the July temperature, when the flowering buds are formed, and the pollen loading of the following year are highly correlated in the region (Autio and Hicks, 2004; Huusko and Hicks, 2009). Other climatic factors, such as early spring temperature in the flowering year, where buds may be damaged by frost, and weather during the flowering period, would also have some impact on pollen loading (McCarroll et al., 2003). For Betula this can be explained by the occurrence of different subspecies, each with different temperature requirements, as reflected by their different geographical distributions. Betula in this region comprises two subspecies: B. pubescens subsp. pubescens and B. pubescens subsp. czerepanowii, which are found growing in areas with slightly different temperature regimes (the mountain birch, $B$. pubescens subsp. czerepanowii, is dominant in the far north while the tree birch, $B$. pubescens subsp. pubescens, is more common in the southern half of the northern plot and areas further south). The vegetation survey used for these analyses does not separate the subspecies and, for this reason, the pollen types have also been combined. This may partly explain the above-mentioned features of the results for Betula. Another possible explanation could be that its flowers are differentiated early (before July) in the summer before flowering (Andersen, 1974). The pollen loading of Betula in traps has been shown to be related to previous year June temperature both in Finland (Autio and Hicks, 2004; Hicks, 2006) and in Denmark (Nielsen et al., 2010), although Dahl and Strandhede (1996) found a positive relation to temperature for a longer period, May-July of the previous year, in southern Sweden. In the present study, we divided the years based on July temperature, as this is most strongly related to the temperature signal it is possible to reconstruct from tree-growth proxies (McCarroll et al., 2003; Young et al., 2012). The dendro and pollen records are linked at the near annual time resolution, because both correspond statistically significantly to $T_{\text {July-1 }}$. Using the long needle production record and the instrumental July temperature record it is possible to successfully predict PARs (Jalkanen et al., 2008). Although temperatures in the different summer months are correlated, there could be an effect on Betula pollen productivity of June temperature variations which is missed by this analysis. However, even using all years together, the relationship between Betula pollen loading in the traps and volume in the surrounding vegetation is not significant (Sugita et al., 2010).

\section{The robustness of the tree volume reconstruction}

Reconstruction of tree volume using the model presented here is based on the assumption that the surrounding vegetation is 
(a)

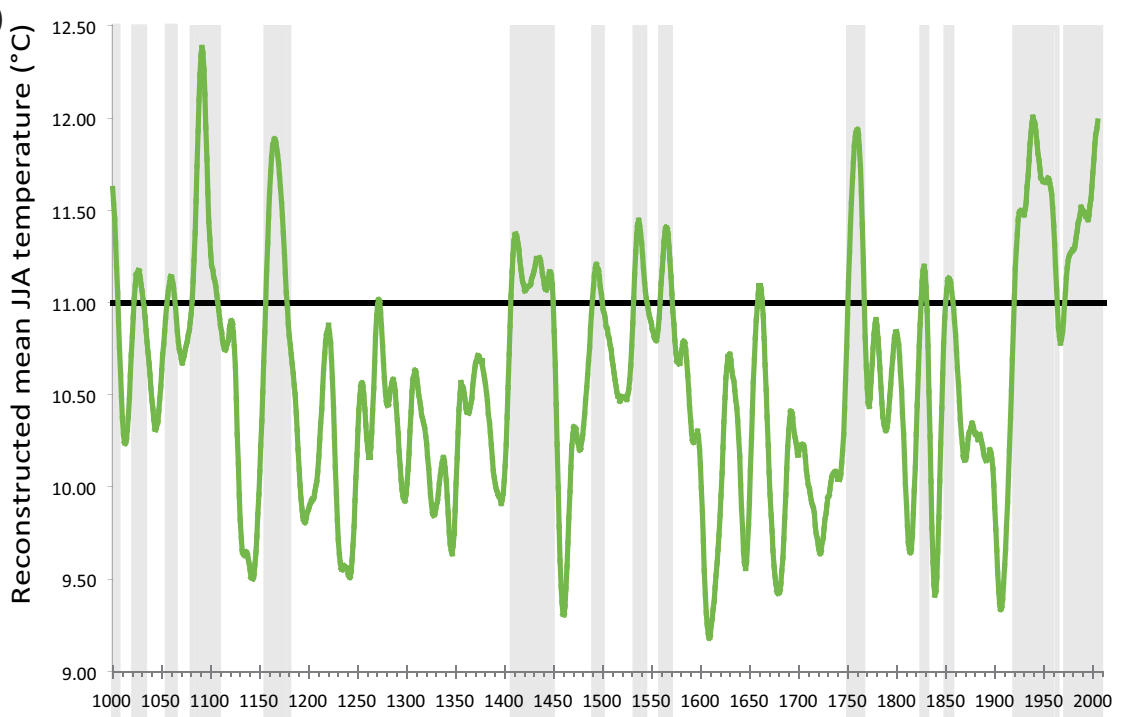

(b)

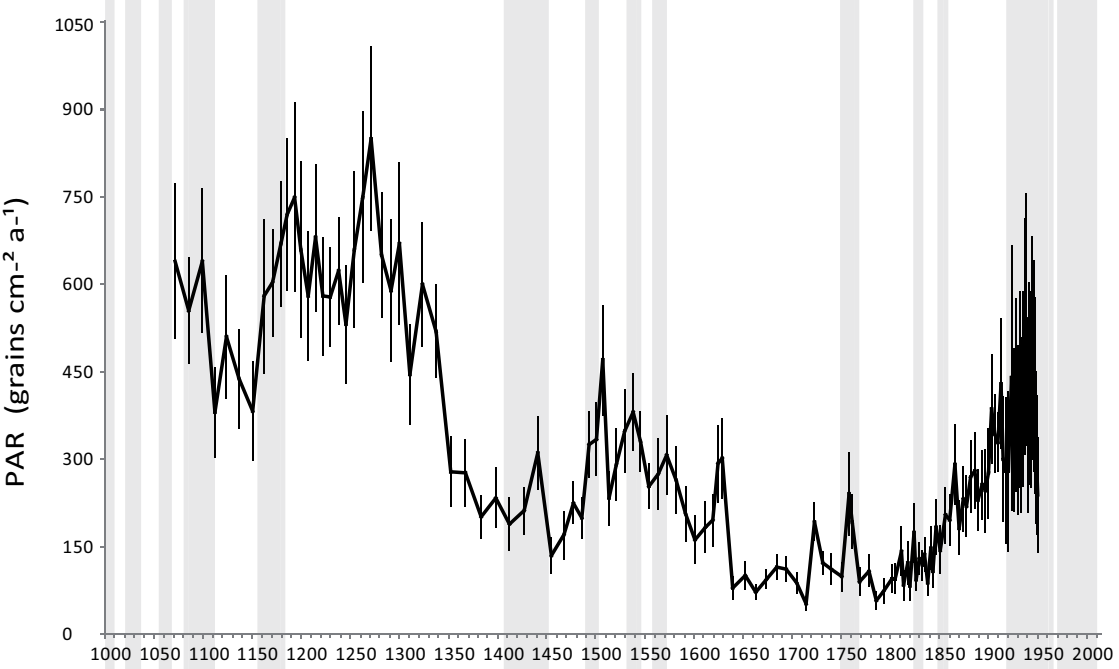

(c)

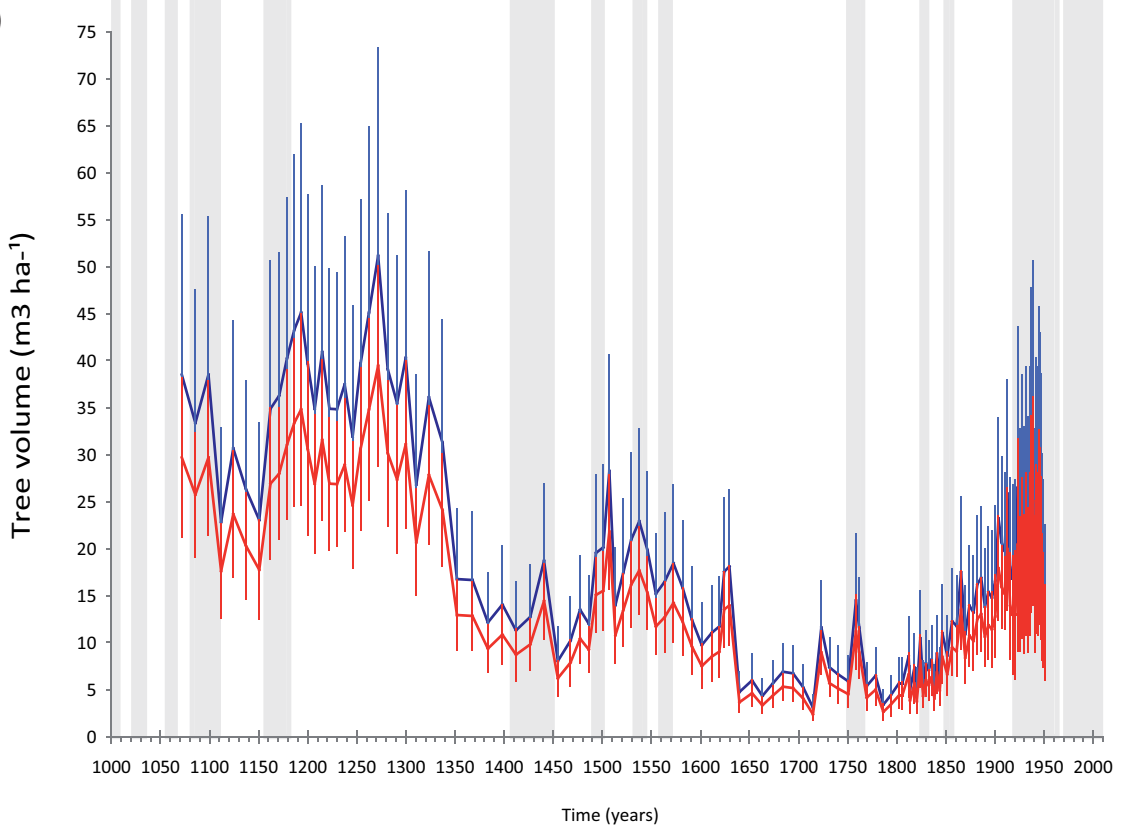

Figure 4. Reconstructed tree volume $\left(\mathrm{m}^{3} \mathrm{ha}^{-1}\right)$ of pine within a 14- $\mathrm{km}$ radius of the Palomaa mire using absolute pollen productivity during cold (blue) and warm (red) years (c), in relation to mean July temperature below and above $12{ }^{\circ} \mathrm{C}$, respectively. The original PAR curve (black) used as the basis for the reconstruction is also shown (b). The dendro-based reconstruction of mean JJA temperature (Young et al., 2012) for Europe at $69^{\circ} \mathrm{N}$ is illustrated at the top (a). Periods of distinctly high summer temperature are highlighted by shading. This figure is available in colour online at wileyonlinelibrary.com/journal/jqs. 
Figure 5. (a) Composite tree volume of pine (brown) produced by taking the reconstruction based on APPE for 'warm' years for those periods where the dendro JJA curve exceeds the $11^{\circ} \mathrm{C}$ threshold and the APPE for 'cold' years for those periods where JJA temperature falls below $11^{\circ} \mathrm{C}$ plotted overlaying the dendro JJA curve (green) which has been smoothed with a 15-year Gaussian filter (Young et al., 2012). Periods of distinctly high summer temperature are highlighted by shading. The dashed lines indicate high peaks and distinct lows in tree volume. (b) The time period blocks within which tree volume is similar. (c) The circles represent the $14-\mathrm{km}$ pollen source area around the Palomaa mire to which the tree volume reconstruction applies and the horizontal line crossing each circle is the hypothesized position of the northern limit of continuous pine forest during that time block. This figure is available in colour online at wileyonlinelibrary.com/ journal/jqs. (a)

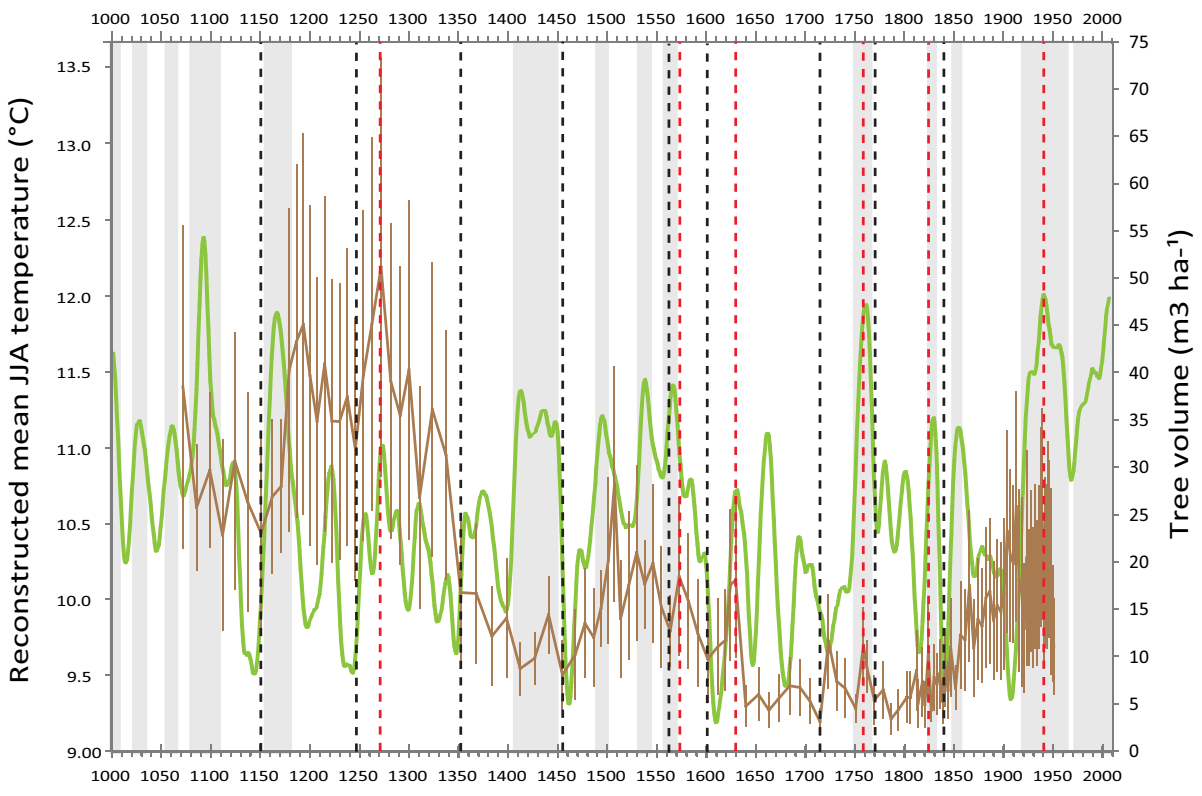

\begin{tabular}{l|l|l|l|l|l|} 
(b) Time period blocks & A & B & C & D & E \\
\cline { 2 - 6 }
\end{tabular}
(c) Nothern limit of continuous pine forest
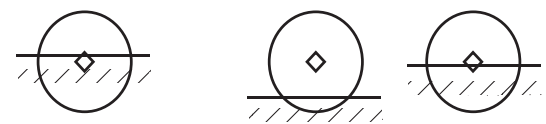

homogeneous. This assumption only partly holds true for the current study site, as it is located at the edge of the ecotone between the mixed boreal forest where pine is dominant, and the birch-dominated forest to the north (Fig. 1). However, within $14 \mathrm{~km}$ of individual sites mixed pine-birch vegetation is dominant across most of the landscape, with the exception of non-pollen-producing water bodies, and this situation also holds true out to $50 \mathrm{~km}$ away from the site. Pinus and Betula are the only abundant tree species in the region and these occur in a mixture throughout without large well-defined vegetation patches, such as are often present in more human-impacted landscapes. Therefore, it is reasonable to assume that the vegetation in the Palomaa region is homogeneous for the model calculation.

\section{Tree volume changes relative to changes in summer temperature}

When the 'warm' and 'cold' values of APPEs are selected on the basis of the dendro JJA temperature curve, the variation of the tree volume estimates becomes smaller, which is feasible based on our current understanding of the forest dynamics in the region. The low-frequency curve of the tree volume estimates (Fig. 5a) shows five distinctive time-periods (blocks A-E in Fig. 5b) that do not coincide with periods of high or low JJA, and thus appear to be capturing regional variations in tree volume. Meanwhile, a number of the highfrequency changes, which are visible within each timeperiod block (Fig. 5a, red and black dashed vertical lines), show variations in pollen loading, or PARs, in response to July temperature. This dual signal is to be expected with a record of this temporal resolution as tree volume can only increase slowly while pollen production varies from one year to the next.

A time lag between a change in JJA temperature and the change in tree volume is to be expected; however, the rates and directions of changes in PARs would differ from those in pine volume. For a dense, mature mixed-age forest to be established a long warm period is required. On the other hand, if a mature forest is taken as the starting point, when temperature drops tree volume will not change immediately but the trees themselves will produce far less pollen or even stop flowering. This state can potentially continue for well over 100 years (R. Jalkanen, Finnish Forest Research Institute, Rovaniemi, Finland, pers. comm., 2011). Eventually, if cold conditions persist some of the trees will die but, more significantly for the forest as a whole, during a long cold period no new seedlings will be produced and gradually the age structure of the forest will change, so that only middle-aged and old trees exist. If temperature then increases, the majority of these trees can immediately increase their pollen production and seed production can once more take place. New seedlings will start the regeneration of the population but these new trees cannot produce pollen until they are around 25 years old. Thus, the change in PAR in response to a climate cooling can be very fast, while a longer lag is expected in response to a warming. This difference in rate of change is seen in Fig. 5. The period of greatest tree volume between AD 1170 and 1340 comes some 100 years after the two really warm phases of AD 1080-1110 and 11501180, while the period of lowest tree volume between AD 1630 and 1810 starts with a sudden fall some $20-50$ years after the dramatic fall in JJA temperature that marks the start of the Little Ice Age. During this very cold phase many of the trees will have stopped flowering altogether, although, as the fossil tree record shows (Young et al., 2012), some were still present. Sudden drops to Pinus PAR values of less than 150 grains $\mathrm{cm}^{-2} \mathrm{a}^{-1}$ should be interpreted bearing this in mind.

The location of the Palomaa mire is just north of the present northern limit of continuous pine forest. In response to the 20th century change in climate (increase in the length of the growing season rather than a clear increase in July temperature, Finnish Meteorological office, Savolainen et al., 2011) the 
northern limit of pine forest in northern Finland is moving northwards at a mean rate of $100 \mathrm{~m} \mathrm{a}^{-1}(6 \mathrm{~km}$ between 1935 and 1995, Sirén, 1998; Juntunen et al., 2002). That the pine forest has also had a more northerly limit in the past is suggested by the presence of isolated old pines north of Palomaa. One nearby tree is at least 400 years old, which would place its time of germination during the slightly warmer period of the 1500s. The present mean tree volume for pine at Utsjoki, far north of the continuous pine forest area where discrete patches of pine forest exist within the mountain birch woodland, is $3 \mathrm{~m}^{3} \mathrm{ha}^{-1}$ (Tomppo et al., 2008) and for the centre of the pine-dominated area south of $68^{\circ} \mathrm{N}$, well to the south of Palomaa, $21.9 \mathrm{~m}^{3} \mathrm{ha}^{-1}$ (Katila and Tomppo, 2001), although average values of $39.3 \mathrm{~m}^{3} \mathrm{ha}^{-1}$ are recorded for northern Lapland as a whole (Ylimartimo, 2007). Our reconstructed volumes for the modern time are in keeping with the present-day range.

The falls in tree volume in our reconstruction (Fig. 5a) are always abrupt and mostly of the order of $12 \mathrm{~m}^{3} \mathrm{ha}^{-1}$ : from 39 to $26 \mathrm{~m}^{3} \mathrm{ha}^{-1}$ around AD 1070 over a period of perhaps 30 years (sample resolution at this point is ca. 15 years), from 31 to $17 \mathrm{~m}^{3}$ $\mathrm{ha}^{-1}$ around AD 1340 and from 18 to $5 \mathrm{~m}^{3} \mathrm{ha}^{-1}$ around AD 1630 and at least the latter two occur some time after the dendro record shows a change to low temperatures (150 and 50 years, respectively). This must be because of the persistence of trees once established, with perhaps the length of time before the 'collapse' threshold is reached being related to both the density of the forest before the temperature change and the magnitude of the temperature drop. What we may also be seeing is a movement of the continuous pine forest limit across the Palomaa site (Fig. 5c).

For this study we have considered July temperature as the main driver of pollen productivity and have used mean JJA temperature for the climate record but we have not been able to address the situation where both of these temperature conditions are constant but the growing season is starting earlier. With a longer growing season the trees also grow better and potentially produce more pollen, and the tree line may shift northwards. It should also be remembered that the dendro JJA temperature curve is one for a whole region at $69^{\circ} \mathrm{N}$ but we are dealing with a small area in the centre of that range.

\section{Comparison with previous biomass reconstruction}

Very few reconstructions of tree volume of this type have been attempted. Seppä et al. (2009) reconstructed biomass of pine, spruce and birch from PARs calculated from the sediments of two lakes in southern Finland. Their reconstruction is for the whole of the Holocene and is expressed in $\mathrm{tha}^{-1}$. The scale of the record is such that it is not possible to pinpoint either Medieval times or the Little Ice Age. The last 1000 years shows large fluctuations between 12 and $60 \mathrm{t} \mathrm{ha}^{-1}$, but the difference in biomass unit and in the method of calculation (the correlation between the PARs of the three tree taxa in the surface sediments of the lakes and their present biomass record for a zone out to only $4.5 \mathrm{~km}$ around the lake) make a comparison difficult.

\section{Conclusion}

We conclude that, even when the errors on the calculations are large, it is still possible to obtain a low frequency tree volume change record for pine from its PAR record and that the estimates of tree volume can be improved by considering cold and warm periods independently. However, when the temporal resolution of the record is such that individual samples represent a period of time over which tree growth is relatively small then the high-frequency record is still primarily a record of changes in pollen productivity due to changes in summer temperature. At times when summer temperature falls well below the critical level for pollen production the PARs underestimate tree volume because the absence of pollen causes a 'blind spot' in the record, so Pinus PAR values of below 150 grains $\mathrm{cm}^{-2} \mathrm{a}^{-1}$ cannot give the true picture of tree volume. Because the PAR record always contains the dual signal of tree volume and pollen productivity, knowing the temporal resolution of the record, we can predict that the low frequency reflects tree volume and the high frequency temperature but we may not be able to put values on the changes in these two signals without the backup of an independent temperature record.

Acknowledgements. We thank Heidi Hyyppä for doing the pollen counting on the Palomaa profile and Antti Huusko for providing the SE calculations on the Pinus PARs. The idea for the paper arose from discussions within the NordForsk networks POLLANDCAL and LANDCLIM. This work is a contribution to the EU 6FP project no 017008: Millennium, European climate of the last millennium. S.S. was supported by the Estonian Mobilitas Programme (MTT3) and F.M. by the VR Linnaeus grant 'Lund Centre for studies of Carbon Cycle and Climate Interaction, LUCCl' (grant number: VR 349-2007-8705) and the French National Center of Research.

Abbreviations. APPE, absolute pollen productivity estimate; $\mathrm{Cl}$, confidence interval; JJA, June-July-August; PAR, pollen accumulation rate; $\mathrm{SE}$, standard error.

\section{References}

Andersen ST. 1974. Wind conditions and pollen deposition in a mixed deciduous forest. II. Seasonal and annual pollen deposition 19671972. Grana 14: 64-77.

Andersen ST. 1980. Influence of climatic variation on pollen season severity in wind-pollinated trees and herbs. Grana 19: 47-52.

Autio J, Hicks S. 2004. Annual variations in meteorological conditions and pollen deposition on the fell Aakenustunturi in northern Finland. Potential for using fossil pollen as a climate proxy. Grana 43: 31-47.

Barnekow L, Loader NJ, Hicks S, et al. 2007. Strong correlation between summer temperature and pollen accumulation rates for Pinus sylvestris, Picea abies and Betula spp. in a high-resolution record from northern Sweden. Journal of Quaternary Science 22: 653-658.

Bennett KD, Hicks S. 2005. Numerical analysis of surface and fossil pollen spectra from northern Fennoscandia. Journal of Biogeography 32: $407-423$.

Clymo RS. 1998. A high-resolution sampler of surface peat. Functional Ecology 2: 425-431.

Dahl A, Strandhede SO. 1996. Predicting the intensity of the birch pollen season. Aerobiologia 12: 97-106.

Davis MB, Deevey ES. 1964. Pollen accumulation rates: estimates from late-glacial sediment of Rogers Lake. Science 145: 1293-1295.

Giesecke T, Fontana S. 2008. Revisiting pollen accumulation rate estimates from lake sediments. The Holocene 18: 293-304.

Goslar T, Van der Knaap WO, Hicks S, et al. 2005. Radiocarbon dating of modern peat profiles: pre- and post-bomb ${ }^{14} \mathrm{C}$ variations in the construction of age-depth models. Radiocarbon 47: 115-134.

Goslar T, Van der Knaap WO, Kamenik C, et al. 2009. Age-depth modelling of an intensively dated modern peat profile. Journal of Quaternary Science 24: 481-499.

Hicks S. 2001. The use of annual arboreal pollen deposition values for delimiting tree-lines in the landscape and exploring models of pollen dispersal. Review of Palaeobotany and Palynology 117: 1-29.

Hicks S. 1994. Present and past pollen records of Lapland forests. Review of Palaeobotany and Palynology 82: 17-35.

Hicks S. 2006. When no pollen does not mean no trees. Vegetation History and Archaeobotany 15: 253-261.

Hicks S, Amman B, Latalowa M, et al. 1996. European pollen monitoring programme: project description and guidelines. University of Oulu, Oulu. 
Hicks S, Tinsley H, Huusko A, et al. 2001. Some comments on spatial variation in arboreal pollen deposition: first records from the Pollen Monitoring Programme (PMP). Review of Palaeobotany and Palynology 117: 183-197.

Hicks S, Tinsley H, Pardoe HS, et al. 1999. Supplement to the guidelines. European pollen monitoring programme. University of Oulu, Oulu.

Huusko A, Hicks S. 2009. Conifer pollen abundance provides a proxy for summer temperature: evidence from the latitudinal forest limit in Finland. Journal of Quaternary Science 4: 522-528.

Jalkanen R, Hicks S, Aalto T, et al. 2008. Past pollen production reconstructed from needle production in Pinus sylvestris at the northern timberline: a tool for evaluating palaeoclimate reconstructions. Silva Fennica 42: 499-513.

Juntunen V, Neuovonen S, Norokorpi Y, et al. 2002. Potential for timberline advance in northern Finland as revealed by monitoring 1983-99. Arctic 55: 345-361.

Katila M, Tomppo E. 2001. Selecting estimation parameters for the Finnish multisource forest inventory. Remote Sensing of Environment 76: 16-32.

Kuoppamaa M, Goslar T, Hicks S. 2009a. Pollen accumulation rates as a tool for detecting land-use changes in sparsely settled boreal forest. Vegetation History and Archaeobotany 18: 205-217.

Kuoppamaa M, Huusko A, Hicks S. 2009b. Pinus and Betula pollen accumulation rates from the northern boreal forest as a record of interannual varation in July temperature. Journal of Quaternary Science 24: 513-521.

Lisitsyna O, Hicks S, Huusko A. 2012. Do moss samples, pollen traps and modern lake sediments all collect pollen in the same way? A comparison from the forest limit area of northernmost Europe. Vegetation History and Archaeobotany (in press). DOI: 10.1007/ s00334-011-0335-x.

Maher L. 1981. Statistics for microfossil concentration measurements employing samples spikes with marker grains. Review of Palaeobotany and Palynology 32: 153-191.

McCarroll D, Jalkanen R, Hicks S, et al. 2003. Multiproxy dendroclimatology: a pilot study in northern Finland. The Holocene 13: 829838.

Mosimann JE. 1965. Statistical methods for the pollen analyst. In Handbook of Paleontological Techniques, Kummel B, Raup D (eds), Freeman: San Francisco; 636-673.

National Land Survey of Finland. 2002. Land Cover and Forest Classification. http://www.maanmittauslaitos.fi/Default. asp?id=49716.08.2002 [accessed 20 May 2009].

Nielsen AB, Moller PF, Giesecke T, et al. 2010. The effect of climate conditions on inter-annual flowering variability monitored by pollen traps below the canopy in Draved Forest, Denmark. Vegetation History and Archaeobotany 19: 309-323.
Prentice IC. 1985. Pollen representation, source area, and basin size: toward a unified theory of pollen analysis. Quaternary Research 23: 76-86.

Räsänen S, Suutari H, Nielsen AB. 2007. A step further towards quantitative reconstruction of past vegetation in Fennoscandian boreal forests: pollen productivity estimates for six dominant taxa. Review of Palaeobotany and Palynology 146: 208-220.

Savolainen O, Kujala S, Sokol C, et al. 2011. Adaptive potential of northernmost tree populations to climate change with emphasis on Scots Pine (Pinus sylvestris L.). Journal of Heredity 102: 526-536.

Seppä H, Alenius T, Muukkonen P, et al. 2009. Calibrated pollen accumulation rates as a basis for quantitative tree biomass reconstructions. The Holocene 19: 209-220.

Seppä H, Hicks S. 2006. Integration of modern and past pollen accumulation rate (PAR) records across the arctic tree-line: a method for more precise vegetation reconstructions. Quaternary Science Reviews 25: 1501-1516.

Sirén G. 1998. Results and conclusions of pine advance in subarctic Finland in the 20th century. Finnish Forest Research Institute Research Papers 677: 7-16.

Sokal R, Rohlf F. 1981. Biometry. W.H. Freeman: New York.

Stockmarr J. 1971. Tablets with spores used in absolute pollen analysis. Pollen et Spores 13: 615-621.

Stuart A, Ord JK. 1994. Kendall's advanced theory of statistics, Vol. 1. Edward Arnold: London.

Sugita S. 1993. A model of pollen source area for an entire lake surface. Quaternary Research 39: 239-244.

Sugita S. 1994. Pollen representation of vegetation in quaternary sediments: theory and method in patchy vegetation. Journal of Ecology 82: 881-897.

Sugita S, Hicks S, Sormunen H. 2010. Absolute pollen productivity and pollen-vegetation relationships in northern Finland. Journal of Quaternary Science 25: 724-736.

Sutinen R, Hyvönen E, Ruther A, et al. 2005. Soil-driven timberline of spruce (Picea abies) in Tanaelv Belt-Lapland Granulite transition, Finland. Arctic, Antarctic. and Alpine Research 37: 611-619.

Tomppo E, Haakana M, Katila M, et al. 2008. Multi-source National Forest Inventory, Methods and Applications. Springer: Berlin.

van der Knaap W, van Leeuwen J, Svitavská-Svobodová H, et al. 2010. Annual pollen traps reveal the complexity of climatic control on pollen productivity in Europe and the Caucasus. Vegetation History and Archaeobotany 19: 285-307.

Ylimartimo J. (ed.,), 2007. Metsä ja ympäristö kertomus, METLA report, Finnish Forest Research Institute, Vantaa, Finland.

Young GHF, McCarroll D, Loader NJ, et al. 2012. Changes in atmospheric circulation and the Arctic Oscillation preserved within a millennial length reconstruction of summer cloud cover from northern Fennoscandia. Climate Dynamics (in press). DOI: 10.1007/s00382-011-1246-3. 